\title{
SENTIMENT ANALYSIS AND OPINION MINING ON PRODUCTS, MOVIES, TOURISM REVIEWS USING MACHINE LEARNING TECHNIQUES
}

\author{
Qureshi Mahek Fatima \\ $3^{\text {rd }}$ Year Btech (CSE) \\ P.E.S College of Engineering, Aurangabad, \\ Maharashtra, India
}

\begin{abstract}
Sentiment Analysis and Opinion Minning are one of the fast - emerging fields. Today our world is technologically advanced. There is extensive use of social media among the people. People express their opinions about their concerned domain on social networking sites or online websites. Sentiment Analysis helps to analyze people's reviews and opinions. This helps businesses, organizations, hotels, institutions, tourism industry, to know people's needs and try to modify their products and services according to it to yield the profits. Sentiment Analysis and Opinion Mining is performed in various domains like product reviews, movie reviews, tourism, education, politics, sports, etc. Some of the domains and the techniques used to analyze the Sentiment Analysis and Opinion Mining are discussed in this paper.
\end{abstract}

Keywords - Sentiment Analysis, Machine Learning, Naïve Bayes, SVM (Support Vector Machine).

\section{INTRODUCTION}

We live in a technologically advanced world. With the development of social media applications and its enormous use by the people, the world has been converted into an online world. Sentiment analysis and Opinion Mining helps to classify peoples opinions and reviews (e.g. a positive or negative opinion) within the text, whether a whole document, paragraph, sentence, or clause[1]. Today it is essential to know about the feedback, reviews, emotions of the users for businesses, movie makers, organizations, schools, colleges, tourist places, etc. This helps the concerned authorities to know what are the users need, what they expect from their products or services. Due to the advancement in social media people are expressing their opinions on various things quite openly. For people who want to buy some products or invest in some services from online websites, it is a cherry on the cake to know about the opinions, suggestions or, ratings of the people who have pre-owned it. From these reviews, they can

\author{
Sayyed Mustakim \\ $3^{\text {rd }}$ Year Btech (CSE) \\ P.E.S College of Engineering, Aurangabad, \\ Maharashtra, India
}

understand and decide whether it will be a bonus to buy that product or invest in that service or not. Likewise for the travel enthusiast who loves to explore new places, can go through online reviews on that particular place, which will help them to know whether that place would be a worth visit or not. Sentiment Analysis is an equally beneficial technique for the hotel industry. As today we can book hotels online. Before visiting some unknown places now people can go through online reviews of the people to know which hotel would be best to reside in. For the people making some unique cannot and posting it on social media, reviews analysis helps a lot to learn people's expectations from them and tailor their content according to their expectations or opinions. The School or college authorities too have a website where there is an option of feedback. Students, Faculty or, the Parents can write their opinions or suggestions for any particular thing they feel about. This helps the Institution authorities to work towards the suggestions in the feedback and improve the quality of the institute. Politics is another domain that people are interested in. As we all live in a demoracy. Time to time there are certain elections. There are certain pools on social networks, people write their opinions and all these reviews and opinions help the people to guess who can win the upcoming elections. Sentiment Analysis or Opinion Mining is an emerging field. There are various steps through which $\mathrm{SA}$ and $\mathrm{OP}$ are performed to classify the reviews. Firstly data is extracted from a concerned site, mostly Amazon, Flipkart, IMBD, Twitter, etc. $[1][2][3][4][5][6][7][9][16][17]$. Later the data is pre-processed using various techniques for removal of stop words, punctuation marks, etc. using POS Tagger, etc. [2][4][5][6][9]. The next step is the feature extraction of data using various feature extraction techniques like Unigram and Bigram[1][7].In some researches, there is a calculation of polarity score (positive or negative) using the available analyzing tools like SentiWordNet[6][9]. Lastly, the classifiers in Machine Learning are used to classify the reviews in to negative or positive and calculate the accuracy and precision of the model. The most commonly used classifiers are Naïve Bayes and 
Support

Vector

Machine

(SVM)[1][2][3][4][5][6][7][8][14][17].In Section 2 there is a discussion on Sentiment Analysis on Product Reviews. In Section 3 there is a discussion on Sentiment Analysis On Movie Reviews. Section 4 discusses Sentiment Analysis In Tourism and Section 5 discusses the Conclusion.

\section{Sentiment Analysis On Product Reviews}

In case Today, as technology has developed enormously, with the development of social media and its extensive popularity among the people, the world has transformed into an online world. From small businesses to big companies everyone has directed their focus in the marketing and development of their businesses online. There are various e-commerce websites like Amazon, Flipkart, Myntra, etc., which sells a variety of products. The business owners feel the need to know people's opinions and feedback regarding their products, services, brands, etc. This helps them to modify their products, services, and brands according to the user's needs. Likewise, the users/people before buying a product or investing in some company's services needs to know the reviews of the people who have pre-owned it. This helps them to make an appropriate decision whether to buy or invest in it or not. The reviews on online sites help people to know other people's opinions. Sentiment Analysis and Opinion Mining is a technique to mine people's opinions or reviews from a text and classify them into positive, negative, or neutral[10]. For example., if someone wants to buy a certain mobile can be from Amazon. Firstly that person will see the reviews and ratings on that product whether the people who have bought it found it's performance satisfactory or not. This will help people to invest their money in reliable things. In Sentiment Analysis or Opinion Mining first step is to extract or mine the data from the concerned online site. Mostly data from Amazon[1][2][3][4], Flipkart[1][5], Epinions, Cnet[4] have been used to perform the Sentiment evaluation. The data extracted can be labeled or an un-labeled format. In the Second step pre-processing of data is done using various available techniques, mainly POS tagger is used to extract nouns, adjectives, adverbs, and the common linguistic characteristics from the reviews[2][4][5][6][9]. There is the removal of stop words, emojis, punctuation marks which don't have a certain meaning. After pre-processing by using available analyzing tools like SentiWordNet, etc. there is a generation of sentiment score to the dataset[6][9],. For the extraction of features, some researchers used Unigram and Bigram feature extraction methods[1][7]. After all these steps the Machine Learning approaches are used to classify the reviews into positive or negative. Most commonly used ML classifiers are Naïve Bayes [1][3][4][5], SVM(Support Vector Machine)[1][2][3], Maximum Entropy[1], etc. Refer Table 1

\section{Sentiment Analysis On Movie Reviews}

This is an era of technological advancement. Everyday someone in any corner of the world invents something. If we take ourselves back a decade, we can understand how far we have come in the technological domain. One such evolution has happened in the entertainment industry. Before the technology took over us, it was a usual practice to watch a recent movie in a cinema hall or whenever it used to telecast on television. Dvd players were also available to watch a movie by inserting the desired cd. But the availability of the cd uses to take quite a lot of time. Now, this is not the scenario. A wide range of movie applications and websites have been developed that contain thousands of movies in it. For example Netflix, Amazon Prime, etc. The people can now just download that application, pay a certain subscription charge, and watch as many movies or whichever movie they want anytime, anywhere. As everyone loves entertainment and is a bit choosy of the genre of the movie they like, people want to invest their valuable time watching something useful. So, the user's opinions and reviews play an important role. By going through the reviews on a certain movie, people can get an idea if it's a great choice to watch it or not. For the moviemakers to reviews are necessary, which will help them to understand are the people loving their content or not and what are their expectations. Here Sentiment Analysis or Opinion Mining plays an important role. Sentiment Analysis or Opinion mining extracts or mines people's opinions and reviews and classify them into positive, negative, or neutral [10]. Firstly step for sentiment analysis is the extraction of data, mostly for movie reviews IMBD [6], Bo Pang[8], and Amazon[7] website reviews are used. The second step is preprocessing of data, using POS Tagger[2],[4][5][6][9] and there is stop word removal. Common feature extraction techniques used are Unigram and Bigram[1][7]. The next thing done is generating a sentiment score using available analyzing tools like SentiWordNet, WordNet, Opinion Lexicon[6][9]. Now the classifiers are used to classify positive or negative, mostly Machine Learning approaches are used like Naïve Bayes, SVM, Genetic Algorithm, KNN, Decision tree, etc [1][2][3][4][5][6][7][8]. Refer Table 2

\section{SENTIMENT ANALYSIS ON TOURISM}

In the modern era of technology and development, the biggest platforms for the interaction of people to express their feelings, Sentiments, and their Opinions are Social Media, Blogs, Websites, etc. For the tourism sector, it has been a massive change from being offline to online on the internet so they can easily analyze the customer's feedback concerning their facilities, services, and management. Different tourism companies and hotels always try to analyze the feedback of their clients. Analyzing the reviews and opinions of consumers help the merchandise to modify the services, management, staff selection, etc. Similarly, for the user, he also tries to figure out where we can plan a trip for his holidays, stay in hotels, visiting some historical places, etc. Based on reviews opinions and comments from the previous consumers of that particular merchandise. The user will get an idea of whether he wants to 
go with it or not. Sentiment analysis or opinion mining is the area deals with judgments, responses as well as feelings which are generated from text [11]. If we take an example of a person who wants to visit the historic place of Egypt pyramids for his holidays so he can go through different tourism websites like booking.com, airbnb.com tripadvisor.com, etc. Where he can gain some information about that place and also reviews of people who visited that place before. Then he would be able to decide whether he wants to go there or not. In this process of analysis different data sets have been used for analyzing the sentiments and opinions of people. Mostly social media blogs, tourism websites have been used for the extraction process of the data. Firstly the data collection has been done using different automated programs [12]. Here comes the second step which includes processing of data which results in spelling corrections, normalization, filtering the text, case folding, etc [12]. In the third step, it aims to obtain the classification of data using different techniques like text blog python library, text mining approach, Fuzzy c-means clustering, etc. By which the data can be categorized into positive, negative, and neutral stages [12] [13] [14]. The last step comes up with the classification model which has been made using techniques like K-nearest Neighbor, Support Vector Machine, Logistic Regression, Random Forest Classifier, Naïve Bayes, etc [14]. Refer Table 3

Table -1 Comparative Analysis On Product Reviews

\begin{tabular}{|c|c|c|c|c|}
\hline Sr.no & $\begin{array}{c}\text { Paper } \\
\text { Title }\end{array}$ & $\begin{array}{l}\text { Algorithm } \\
\text { Used }\end{array}$ & Datasets & Outcomes \\
\hline 1. & $\begin{array}{l}\text { Bordoloi et } \\
\text { al }(2018)[10]\end{array}$ & $\begin{array}{l}\text { Naïve Bayes, } \\
\text { SVM, } \\
\text { Maximum } \\
\text { Entropy }\end{array}$ & $\begin{array}{l}\text { Amazon, } \\
\text { Flipkart } \\
\text { reviews }\end{array}$ & $\begin{array}{l}\text { The ML } \\
\text { approaches } \\
\text { of } \\
\text { classification } \\
\text { are used and } \\
\text { in all the } 3 \\
\text { used datasets } \\
\text { NB } \\
\text { outshines } \\
\text { SVM and } \\
\text { MaxEnt with } \\
\text { the } 81.33 \% \\
\text { accuracy in } \\
\text { one dataset, } \\
80 \% \text { in the } \\
2^{\text {nd dataset, }} \text { and } 78.24 \% \\
\text { in the } 3^{\text {rd }} \\
\text { dataset. }\end{array}$ \\
\hline 2. & $\begin{array}{l}\text { Jabbar et } \\
\text { al }(2019)[2]\end{array}$ & SVM & Amazon & $\begin{array}{l}\text { After the } \\
\text { pre- } \\
\text { processing } \\
\text { of data, the } \\
\text { machine } \\
\text { learning } \\
\text { method of } \\
\text { the SVM } \\
\text { classifier is } \\
\text { used to } \\
\text { classify the } \\
\text { reviews into }\end{array}$ \\
\hline
\end{tabular}

\begin{tabular}{|c|c|c|c|c|}
\hline & & & & $\begin{array}{l}\text { Positive, } \\
\text { negative, and } \\
\text { neutral. By } \\
\text { using this } \\
\text { proposed } \\
\text { method with } \\
\text { SVM the } \\
\text { precision } \\
\text { recorded was } \\
87.88 \% \text {. }\end{array}$ \\
\hline 3. & $\begin{array}{l}\text { Jagdale et al } \\
\text { (2017), [3] }\end{array}$ & $\begin{array}{l}\text { SVM, Naïve } \\
\text { Bayes }\end{array}$ & Amazon & $\begin{array}{l}\text { For the } \\
\text { camera } \\
\text { reviews, the } \\
\text { Naïve Bayes } \\
\text { gets an } \\
\text { accuracy of } \\
98.17 \% \text { and } \\
\text { SVM gets } \\
93.54 \% \text {. }\end{array}$ \\
\hline 4. & $\begin{array}{l}\text { Jeyapriya et } \\
\text { al (2015)[4] }\end{array}$ & Naïve Bayes & $\begin{array}{l}\text { Amazon, } \\
\text { Epinions, } \\
\text { Cnet }\end{array}$ & $\begin{array}{l}\text { By using the } \\
\text { Naïve Bayes } \\
\text { algorithm } \\
\text { the reviews } \\
\text { are classified } \\
\text { into positive } \\
\text { and negative } \\
\text { ones. Aspect } \\
\text { extraction } \\
\text { has given the } \\
\text { accuracy of } \\
80.36 \% \\
\text { using } \\
\text { frequent } \\
\text { itemset } \\
\text { mining. } \\
\text { Sentiment } \\
\text { orientation } \\
\text { provides } \\
92.37 \% \text { of } \\
\text { accuracy for } \\
\text { the given } \\
\text { dataset. }\end{array}$ \\
\hline 5. & $\begin{array}{l}\text { Venkata et } \\
\text { al (2015)[5] }\end{array}$ & Naïve Bayes & Flipkart & $\begin{array}{l}\text { After Pre- } \\
\text { processing } \\
\text { Product } \\
\text { score was } \\
\text { generated by } \\
\text { examining } \\
\text { the rating, } \\
\text { reviews, and } \\
\text { all the } \\
\text { aspects. } \\
\text { Naïve Bayes } \\
\text { classifier } \\
\text { was used to } \\
\text { classify the } \\
\text { reviews. } \\
\text { There has } \\
\text { been given a } \\
\text { comparison } \\
\text { between two } \\
\text { mobile } \\
\text { phones by } \\
\text { displaying } \\
\text { star rating, } \\
\text { polarity } \\
\text { rating, }\end{array}$ \\
\hline
\end{tabular}


International Journal of Engineering Applied Sciences and Technology, 2020

Vol. 5, Issue 6, ISSN No. 2455-2143, Pages 148-153

Published Online October 2020 in IJEAST (http://www.ijeast.com)

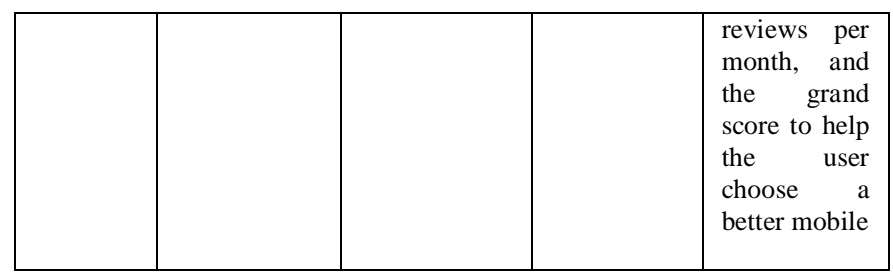

Table -2 Comparative Analysis On Movie Reviews

\begin{tabular}{|c|c|c|c|c|}
\hline $\begin{array}{l}\text { Sr. } \\
\text { No }\end{array}$ & Papers & $\begin{array}{l}\text { Classifiers } \\
\text { Used }\end{array}$ & $\begin{array}{c}\text { Dataset } \\
\text { used }\end{array}$ & End Result \\
\hline 1. & $\begin{array}{l}\text { Sahu et al } \\
\text { (2016)[6] }\end{array}$ & $\begin{array}{l}\text { Decision Tree, } \\
\text { Bagging, } \\
\text { Naïve Bayes, } \\
\text { COCR, KNN. }\end{array}$ & $\begin{array}{l}\text { IMBD } \\
\text { reviews }\end{array}$ & $\begin{array}{c}\text { Random forest } \\
\text { gives the best } \\
\text { accuracy of } \\
88.95 \% \text {. The } \\
\text { rest classifiers } \\
\text { have the } \\
\text { accuracy as } \\
\text { follows, } \\
\text { Decision Tree } \\
87.53 \% \text {, } \\
\text { COCR } \\
82.53 \%, \\
\text { Bagging } 88.57 \\
\%, \text { KNN } \\
88.56 \% \text {, and } \\
\text { Naïve Bayes } \\
54.77 \% . \text { By } \\
\text { comparing this } \\
\text { proposed } \\
\text { model with the } \\
\text { previous } \\
\text { models. This } \\
\text { gives the } \\
\text { highest } \\
\text { accuracy of } \\
88.95 \% \text {. }\end{array}$ \\
\hline 2. & $\begin{array}{l}\text { Mr. B. Narendra } \\
\text { et al (2016) [7] }\end{array}$ & $\begin{array}{l}\text { Naïve Bayes, } \\
\text { Proposed } \\
\text { model- } \\
\text { Apache } \\
\text { Hadoop }\end{array}$ & $\begin{array}{l}\text { Amazon } \\
\text { site }\end{array}$ & $\begin{array}{l}\text { Naïve Bayes } \\
\text { classifier with } \\
\text { stop word } \\
\text { removal and } \\
\text { bigram feature } \\
\text { extraction } \\
\text { method and } \\
\text { got the } \\
\text { accuracy } \\
\text { of81.6\%. } \\
\text { The proposed } \\
\text { method using } \\
\text { Apache } \\
\text { Hadoop } \\
\text { obtained the } \\
\text { precision } 98 \% \text {. } \\
\text { This proposed } \\
\text { method } \\
\text { outshined the } \\
\text { Naïve Bayes } \\
\text { Classifier } \\
\text { technique }\end{array}$ \\
\hline 3. & $\begin{array}{l}\text { M.Govindarajan } \\
\text { et al (2013)[8] }\end{array}$ & Naïve Bayes, & Bo Pang & $\begin{array}{l}\text { The accuracy } \\
\text { obtained by }\end{array}$ \\
\hline
\end{tabular}

\begin{tabular}{|c|c|c|c|c|}
\hline & & $\begin{array}{l}\text { Genetic } \\
\text { Algorithm, } \\
\text { The hybrid } \\
\text { method of } \\
\text { NB-GA }\end{array}$ & & $\begin{array}{l}\text { Naïve Bayes is } \\
91.15 \%, \text { for } \\
\text { the Genetic } \\
\text { Algorithm is } \\
91.25 \% \text { and } \\
\text { the Proposed } \\
\text { hybrid model } \\
\text { of NB-GA is } \\
93.80 \% \text {. }\end{array}$ \\
\hline 4. & $\begin{array}{l}\text { Sharma P et al } \\
(2016)[9]\end{array}$ & $\begin{array}{l}\text { Used } \\
\text { available } \\
\text { Analyzing } \\
\text { tools like } \\
\text { SentiWordNet, } \\
\text { WordNet, } \\
\text { Opinion } \\
\text { Lexicon. }\end{array}$ & IMBD & $\begin{array}{l}\text { The proposed } \\
\text { system is } \\
\text { compared to } \\
\text { three analysis } \\
\text { tools } \\
\text { WordNet, } \\
\text { SentiWordNet, } \\
\text { and Opinion } \\
\text { Lexicon. } \\
\text { Scores are } \\
\text { evaluated } \\
\text { using all these } \\
\text { tools. The } \\
\text { accuracy } \\
\text { obtained for } \\
\text { the WordNet } \\
\text { is } 57 \% \text {, } \\
\text { SentiWordNet } \\
63 \% \text {, Opinion } \\
\text { Lexicon is } \\
70 \% \text { and the } \\
\text { proposed } \\
\text { model is the } \\
\text { highest } \\
\text { accuracy with } \\
81 \% \text {. }\end{array}$ \\
\hline
\end{tabular}

Table -3 Comparative Analysis On Tourism

\begin{tabular}{|c|c|c|c|c|}
\hline Sr.no & Paper Title & $\begin{array}{c}\text { Algorithm } \\
\text { Used }\end{array}$ & Datasets & Outcomes \\
\hline 1. & $\begin{array}{l}\text { Aitor } \\
\text { García, et al } \\
\text { (2012)[15] }\end{array}$ & $\begin{array}{l}\text { Linguistic } \\
\text { tools based } \\
\text { on an } \\
\text { annotated } \\
\text { lexicon }\end{array}$ & Lexical Dataset & $\begin{array}{l}\text { The } \\
\text { obtained } \\
\text { accuracy in } \\
\text { mere } \\
\text { polarity } \\
\text { detection } \\
\text { was } 80 \%\end{array}$ \\
\hline 2. & $\begin{array}{l}\text { Sarah Anis } \\
\text { et al (2020) } \\
{[14]}\end{array}$ & $\begin{array}{l}\text { Naïve Bayes, } \\
\text { K-nearest } \\
\text { neighbor, } \\
\text { Support } \\
\text { Vector } \\
\text { Machine, } \\
\text { Logistic } \\
\text { regression, } \\
\text { Random } \\
\text { forest } \\
\text { classifier }\end{array}$ & $\begin{array}{l}\text { Reviews from } \\
\text { the Kaggle } \\
\text { website. }\end{array}$ & $\begin{array}{l}\text { The support } \\
\text { vector } \\
\text { machine } \\
\text { achieved } \\
86.3 \% \text {, } \\
\text { logistic } \\
\text { regression } \\
\text { achieved } \\
85.9 \% \text {, } \\
\text { Random } \\
\text { forest } \\
\text { classifier } \\
\text { achieved } \\
84.6 \%, \mathrm{~K}- \\
\text { nearest } \\
\text { neighbor, } \\
\text { and Naïve } \\
\text { Bayes } \\
\text { achieved } \\
83.8 \% \text { and }\end{array}$ \\
\hline
\end{tabular}




\begin{tabular}{|c|c|c|c|c|}
\hline & & & & $\begin{array}{l}7.8 \% \\
\text { respectively. }\end{array}$ \\
\hline 3. & $\begin{array}{l}\text { Puteri et al } \\
(2017)[12]\end{array}$ & $\begin{array}{l}\text { Text mining } \\
\text { program } \\
\text { called } \\
\text { Parmeswari } \\
\text { v1.4.0 }\end{array}$ & $\begin{array}{l}\text { Tripadvisor.com } \\
\text { website }\end{array}$ & $\begin{array}{l}\text { The } \\
\text { classifier } \\
\text { model used } \\
\text { in this study } \\
\text { had an } \\
\text { average } \\
\text { accuracy of } \\
85 \% \text {. }\end{array}$ \\
\hline 4. & $\begin{array}{l}\text { Vallikannu } \\
\text { et al } \\
(2019)[16]\end{array}$ & $\begin{array}{l}\text { Domain- } \\
\text { specific on } \\
\text { combined } \\
\text { with lexicon- } \\
\text { based } \\
\text { approach } \\
\text { conceptual } \\
\text { and semantic } \\
\text { analysis } \\
\text { incorporating } \\
\text { with the } \\
\text { machine } \\
\text { learning } \\
\text { method } \\
\text { Naïve Bayes }\end{array}$ & Twitter Tweets & $\begin{array}{l}\text { Using the } \\
\text { conceptual } \\
\text { semantic } \\
\text { analysis } \\
\text { method } \\
\text { performance } \\
\text { of the } \\
\text { sentiment } \\
\text { analysis } \\
\text { improved } \\
\text { with } \\
\text { precision } \\
85.54 \% \text {. }\end{array}$ \\
\hline 5. & $\begin{array}{l}\text { Taweesak } \\
\text { Kuhamanee, } \\
\text { et al } \\
(2017)[17]\end{array}$ & $\begin{array}{l}\text { Decision } \\
\text { Tree, } \\
\text { Support } \\
\text { Vector } \\
\text { Machine, } \\
\text { Artificial } \\
\text { Neural } \\
\text { Network, } \\
\text { and Naïve } \\
\text { Bayes. }\end{array}$ & Twitter Tweets & $\begin{array}{l}\text { Decision } \\
\text { Tree } \\
\text { achieved } \\
79.83 \% \\
\text { accuracy, } \\
\text { SVM } \\
\text { achieved } \\
80.11 \% \\
\text { accuracy, } \\
\text { ANN } \\
\text { achieved } \\
80.33 \% \\
\text { accuracy } \\
\text { and Naïve } \\
\text { Bayes } \\
\text { achieved } \\
55.66 \% \\
\text { accuracy. }\end{array}$ \\
\hline
\end{tabular}

\section{CONCLUSION}

Sentiment analysis and opinion mining use a proper dataset to research the sentiment of individuals . Different algorithms are made but still, there's a niche between better and excellent to beat all problems. From the above data, we will conclude that Support Vector Machine and Naïve Bayes are the foremost frequently used algorithms for sentiment analysis and opinion mining. Although, many organizations are working for creating an ideal algorithm which will solve all the issues and difficulties. Still, it requires many more effort to form one. there's an enormous demand for this technique in our field of labor.

\section{REFERENCE}

[1] https://monkeylearn.com/sentiment-analysis/.

[2] Jabbar. J , Urooj. I , JuSheng Wu , Azeem. N,(2019),"Real- time Sentiment Analysis on E-Commerce Application", (DOI- 10.1109/ICNSC.2019.8743331).

[3] Jagdale. R , Shirsat . Vishal , Deshmukh Sachin,(2017),"Sentiment Analysis on Product Reviews Using Machine Learning Techniques",(10.1007/978-98113-0617-4_61/AISC, Volume 768).

[4] Jeyapriya . A, Selvi Kanimozhi . C.S , (2015), "Extracting aspects and Mining Opinions in product Reviews using Sipervised

Learning Algorithm",(10.1109/ECS.2015.7124967).

[5] Venkata Rajeev, Smrithi Rekha ,(2015),'Recommending Product to Customers Using Opinion Mining Of Online Product Reviews and Features",(10.1109/ICCPCT.2015.7159433).

[6] Sahu Tirath P, Ahuja Sanjeev , (2016), "Sentiment Analysis Of Movie Reviews : A Study On Feature Selection \& Classification Algorithms , (10.1109/MicroCom.2016.7522583).

[7] Mr. B Narendra, Mr. K Uday Sai, Mr.G Rajesh, Mr.K. hemanth , Mr M.V. Chaitanya Teja , Mr K. Deva Kumar ,(2016),'Sentiment Analysis On Movie Reviews: A Comparative Study Of Machine Learning Algorithms and Open Source Technologies,(10.5815/ijisa.2016.08.08).

[8] M. Govindarajan , (2013), Sentiment Analysis of Movie Reviews using Hybrid Method of Naïve Bayes and Genetic Algorithm',(IJACR, Vol 3 issue 13, p139).

[9] Sharma Pallavi , Mishra . N , (2016),"'Feature Level Sentiment Analysis On Movie Reviews",(10.1109/NGCT.2016.78.77432).

[10] Bordoloi Monali , Biswas Saroj Kr,(2018), Sentiment Analysis Of Product Using Machine Learning Techniques: A Comparison among NB , SVM and MaxEnt ",(118(18): 71-83).

[11] www.google.com

[12] Puteri Prameswari, Isti Surjandari , Enrico Loah, (2017),"Opinion Mining from Online Reviews in Bali Tourist Area", (10.1109/ICSITech.2017.8257115).

[13] Gupta Gunjan , Parul Gupta , (2019), Twitter Mining for Sentiment Analysis in Tourism Industry",(101.1109/WorldS4.2019.8903940).

[14] Anis Sarah, Saad Sally, Aref Mostafa , (2020),’Sentiment Analysis of hotel Reviews Using Machine Learning Techniques",(10.1007/978-3-030-58669-0_21).

[15] Aitor Garcia, Sean Gaines , Maria Teresa Linaza,(2012),"A Lexicon Based Sentiment Analysis Retrieval System for Tourism Domain",(e-Review of Tourism Research(eRTR)Vol 10, No 2). 
[16] Vallikanu Ramanathan, T. Meyyappan ,(2019), “Twitter Text Mining for Sentiment Analysis on People's Feedback about Oman Tourism",(10.1109/ICBDSC.2019.8645596).

[17] Taweesak Kuhamanee, Nattaphon Talmongkol, Krit Chaisuriyakul, Wimol San-Um, Noppadon Pongpisuttinun, Surapong Pongyupinpanich, (2017)"Sentiment Analysis of Tourists to Bangkok using Data Mining through Online Social Network", IEEE $15^{\text {th }}$ International Conference on Industrial Informatics (INDIN). 